\title{
Rhabdomyolysis Developed Due to Hypothyroidism: Two Case Reports
}

\author{
Hipotiroidiye Bağlı Gelişen Rabdomiyoliz: Iki Olgu Sunumu
}

\author{
Abdullah Sakin', Kenan Çelik², Ayşegül Sakin², Savaş Öztürk² \\ 'Department of Internal Medicine, Kanuni Sultan Süleyman Research and Training Hospital, İstanbul, Turkey \\ 2Department of Internal Medicine, Haseki Research and Training Hospital, Istanbul, Turkey
}

\begin{abstract}
Introduction: Rhabdomyolysis is a clinical and biochemical syndrome, resulting from the exposure of the skeletal muscle to toxic substances or from diseases. The etiology of the rhabdomyolysis consists of the hereditary deficiency of muscle enzymes; drugs like colchicine, statins, and lithium; convulsion; trauma; viral infections; excessive exercise; and so on. Hypothyroidism is a clinical setting in which thyroid hormones are produced and secreted ineffectively.

Case Report: In our article, two cases of rhabdomyolysis due to hypothyroidism are presented who got the diagnosis of hypothyroidism but had not gotten any treatment. It was seen that the clinical signs and symptoms of the patients recovered quickly with the beginning of hormone replacement, and muscle enzymes decreased back to normal levels.

Conclusion: It should be remembered that depression of the respiratory system, cardiomegaly, pericardial tamponade, angina pectoris, congestive heart failure, and rhabdomyolysis can develop in those patients who are diagnosed with hypothyroidism and yet not treated properly.
\end{abstract}

Keywords: Hypothyroidism, rhabdomyolysis

Received: 28.12.2012 Accepted: 22.02.2013

\section{ÖZET}

Giriş: Rabdomiyoliz iskelet kasının travmatik veya non-travmatik pek çok hastalık sonucunda görülen klinik ve biyokimyasal bir sendromudur. Rabdomiyolizin etiyolojisinde; herediter kas enzim eksiklikleri, kolşisin, statinler ve lityum gibi ilaçlar, konvülziyonlar, travma, viral enfeksiyonlar, aşırı egzersiz gibi nedenler bulunmaktadır. Hipotiroidi; tiroid hormonlarının yetersiz salgılanması sonucunda gelişen bir klinik tablodur.

Olgu Sunumu: Bu yazımızda hipotiroidisi olan ve tedavi almamış iki hastada hipotiroidiye bağlı gelişen rabdomiyoliz olgusu sunulmaktadır. Hastalarımızda hormon replasman tedavisi ile kliniğin hızla düzeldiği ve kas enzimlerinin normale gerilediği görülmektedir.

Sonuç: Hipotiroidi gelişen ve tedavi almayan hastalarda solunum merkezinin depresyonu, kardiyomegali, perikardial tamponad, angina pektoris, konjestif kalp yetersizliği, rabdomiyoliz gelişebileceği unutulmamalıdır.

Anahtar Kelimeler: Hipotiroidi, rabdomiyoliz

Geliş Tarihi: 28.12.2012 Kabul Tarihi: 22.02.2013

\section{Giriş}

Rabdomiyoliz iskelet kasının toksik etkiye maruz kalması veya pek çok hastalık sonucunda görülebilen iskelet kası hücrelerinin akut nekrozu sonucu, kas hücre içeriğinin dolaşıma sızmasıyla gelişen klinik ve biyokimyasal bir sendromdur. Dolaşımdaki toksik kas hücre komponentlerinin salınımına yol açan iskelet kası sarkolemmasının bütünlüğünün hasara uğraması ile ortaya çıkar. Bu; miyoglobulinürik akut böbrek hasarı, hiperkalemi, kardiyak arrest, yaygın intravasküler koagülasyonu içeren komplikasyonlarla sonlanabilir. Rabdomiyolizin etiyolojisinde; herediter kas enzim eksiklikleri, kolşisin, statinler ve lityum gibi ilaçlar, konvülziyonlar, travma, viral enfeksiyonlar, aşırı egzersiz gibi nedenler bulunmaktadır (1). Hipoiroidi tiroid hormonlarının yetersiz salgılanması sonucunda gelişen klinik tablodur. Hastalığın erken belirtileri arasında halsizlik, yorgunluk, isteksizlik, üşüme, soğuğa tahammülsüzlük, saçların kuruması ve incelmesi, tırnakların çabuk kırılması ve terleme azlığı sayılabilir. Hipotiroidiye bağlı miyopatide proksimal kas güçsüzlüğü, kaslarda katılık, kramplar, reflekslerde yavaşlama olur. Ağır hipotiroidide, yardımcı solunum kaslarının et- 
kisi miksödem sebebi ile azalır ve solunum merkezinin depresyonu, alveolar hipotansiyon sendromuna ve karbondioksit retansiyonuna sebep olabilir. Angina pektoris'e nadir olmayarak rastlanır. Bazen de konjestif kalp yetersizliği oluşur. Kaslarda hem kasılma, hem de gevşeme yavaşlamıştır. Böbreklerde kan akımı ve glomerul filtratı azalır. Kadınlarda menstrüel bozukluklar sık görülür (2).

Bu yazımızda hipotiroidisi olan ve tedavi almamış iki hastada hipotrioidiye bağlı gelişen rabdomiyoliz olgusu sunulmaktadır.

\section{Olgu Sunumu}

\section{Olgu 1}

Ellibeş yaşında erkek hasta göğüs ağrısı ve halsizlik yakınmalarıyla başvurdu. Özgeçmişinde kronik iskemik kalp hastalığı mevcuttu ve ilaç olarak sadece asetilsalisik asit 150mg/gün ve isosorbit mononitrat $50 \mathrm{mg} /$ gün kullanmaktaydı. Fizik muayenede alt ve üst ekstremitelerde 4/5 kas gücü kaybı vardı. Hastanın idrar miktarında azalma yoktu, ancak hastanın idrar renginde 1-2 gündür koyulaşma olduğu ve halen devam ettiği öğrenildi. Hastanın laboratuar tetkiklerinde; kreatinin 1,5 mg/dL (0,6-1,3), SGOT 38 U/L (5-34), LDH 350 U/L (125243), CK 1767 U/L (38-174), CK-MB 21 ng/ml (<4,94), kolesterol 346 mg/dl (0-200), trigliserit 321 (0-150) mg/dl, LDL 244 mg/dl (80-180), HDL 37 mg/dl(40-60), hemogram bulguları normal, sedimentasyonu 24 mm/saat olarak saptandı. İdrar rengi açık kırmızı renkte idi, analizinde nadir eritrosit mevcuttu. Tiroid fonksiyon testleri TSH 225 mIU/L(0.27 - 4.2), FT4 0,1 ng/dl (0.93 - 1.7) olarak saptandı. Hastanın EKG sinde sinüs bradikardisi, V3-6 da patolojik Q dalgası mevcuttu. Akciğer grafisinde kardiyotorasik indeks artmıştı. Ekokardiyografisinde sol ventrikülde genişleme, septum ve anterior duvarın mid ve apikal segmentlerinde akinezi, segmenter duvar hareket bozukluğu, sistolik disfonksiyon, hafif derecede mitral yetersizlik, ejeksiyon fraksiyonu \%35 olarak saptandı. Renal ultrasonografisinde (USG) böbrek boyutları normaldi ve herhangi bir obstrüksiyon bulgusu yoktu. Tiroid USG'de tiroid parankimi kaba, hipoekoik ve konturları düzensiz olarak değerlendirildi. Bezin sol lob arka bölümünde $12 \mathrm{~mm}$ çaplı hipoekoik nodül saptandı. 24 saatlik idrar analizinde 265 mg /gün proteinüri saptandı. Hasta hipotiroidiye bağlı rabdomiyoliz olarak kabul edildi. Hastaya levotiroksin tedavisi başlandı. Hastanın kalp yetmezliği açısından da tedavileri düzenlendi. Yapılan tedaviler sonucu hastanın CK değerleri 56 IU/L, TSH değeri 2.31 mIU/L ye geriledi. Hasta endokrin ve kardiyoloji polikliniklerinde takibine alındı.

\section{Olgu 2}

Kırk sekiz yaşında erkek hasta yaygın kas ağrısı ve halsizlik yakınmalarıyla başvurdu. Özgeçmişinde yaklaşık 10 yıl önce tiroidektomi operasyonu öyküsü mevcuttu. Fizik muayenede kas gücü kaybı yoktu. Hastanın idrar miktarında azalma yoktu. Hastanın laboratuar tetkiklerinde; kreatinin 0,99 mg/dL(0,6-1,3), SGOT $128 \mathrm{U} / \mathrm{L}$ (5-34), SGPT 79 U/L (0-55), LDH 675 U/L (125-243), CK 4267 U/L (38-174), CK-MB 51,83 ng/ml (<4,94), kolesterol 216 mg/dl (0-200), LDL 214 $\mathrm{mg} / \mathrm{dl}$ (80-180), hemogram bulguları normal ve sedimentasyonu $5 \mathrm{~mm} / \mathrm{saat}$ olarak saptandı. İdrar analizinde; renk koyu, 2-3 lökosit mevcuttu. Tiroid fonksiyon testlerinde TSH 130 mIU/L (0.27 - 4.2), FT4 $0,35 \mathrm{ng} / \mathrm{dl}(0.93$ - 1.7), FT3 1,3 pg/ml (3.1 - 6.8) olarak saptandı. Hasta- nın EKG sinde sinüs bradikardisi mevcuttu. Akciğer grafisinde özellik yoktu. Ekokardiyografisi normal sınılardaydı. Renal USG böbrek boyutları normaldi. Tiroid USG da rezidüel tiroid dokusuna rastlanmadı. Olgunun anamnezinde travma öyküsü yoktu. Hastanın levotiroksin dışında ilaç kullanımı olmadığı ve levotiroksini de son bir aydır almadığı öğrenildi. Hasta hipotiroidiye bağlı rabdomiyoliz olarak kabul edildi. Hastaya levotiroksin tedavisi başlandı. Yapılan tedaviler sonucu hastanın CK değerleri 40 IU/L, TSH değeri 1.12 mIU/L'e geriledi. Hasta endokrin polikliniği takibine alındı.

\section{Tartışma}

Serum CK değerini yükselten kas travmaları, müsküler distrofiler, ağır egzersiz, miyokard infarktüsü, polimiyozit, rabdomiyoliz gibi olaylar arasında hipotiroidiye bağlı miyopatide yer almaktadır. Hipotiroidi hastalarında CK yüksekliğinin nedeni tam bilinmemekle birlikte birkaç teori ileri sürülmektedir. Bunların başlıcaları; CK aktive edici varlığı, CK klirensinin azalması, ATP eksikliğinden dolayı kastan CK salınımının artması, karbonhidrat metabolizmasını bozulması ve hipotermi olarak sayılabilir. Hipotiroidi miyopatisindeki kas güçsüzlüğü, kramplar, kas atrofi veya hipertrofilerinin serum CK yüksekliği ile pozitif ilişkili olduğu bildirilmektedir (3). Ülkemizde Yarman ve ark. (4) 46 hipotiroidik hastada ile yaptığı çalışmasında miyopatisi olan hastaların \%50'sinde serum CK düzeyi yüksek bulunmuş. CK değeri istatistiki olarakTSH ile arasında pozitif anlamlı bir ilişki gözlemlenmiş ancak tiroid hormonları ve anti-TPO arasında anlamlı ilişki gözlemlenmemiştir. Ancak Giampietro ve ark. (5) yaptığı çalışmasında CK ve tiroid hormonları arasında anlamlı ilişki olduğunu göstermiştir. Aynı zamanda Beyer ve ark. (6) yaptığı çalışmada da CK ve tiroid hormonları arasında anlamlı ilişki olduğunu gözlemlemiştir. Hipotiroidi tanısı tiroid fonksiyon testlerine, klinik bulgulara ve ultrasonografik görüntülere dayanılarak konulmuştur. Hipoiroidi tiroid hormonlarının yetersiz salgılanması sonucu gelişir. İnflamatuar olmayan miyopati nedenleri arasında tiroid hastalıkları ve ilaçlar da bulunmaktadır. Hipotiroidi veya hipertiroidi şeklindeki tiroid fonksiyon bozuklukları miyopati nedeni olabilmektedir. Ağır hipotiroidide, yardımcı solunum kaslarının etkisi miksödem sebebi ile azalır ve solunum merkezinin depresyonu, alveolar hipotansiyon sendromuna ve karbondioksit retansiyonuna sebep olabilir. Kalp büyüyebilir ve nabız yavaşlamıştır (7). Her iki olguda da sinüs bradikardisi mevcuttu. Rabdomiyoliz tanıSı, anamnez ve fizik muayene sonucu şüphelenilir ve laboratuar testleri ile doğrulanarak konulabilmektedir. Rabdomiyoliz tüm ABY(Akut Böbrek Yetmezliği) vakalarının \%8'inden sorumludur. Rabdomiyoliz sırasında ABY gelişmesinde çeşitli faktörler rol oynar. Kaslardan açığa çıkan miyoglobin hem direkt toksik etki ile hem de tübüler tıkaçlara yol açarak ABY gelişmesine sebep olur (8). Rabdomiyoliz tanısında klinik, idrar renginin koyulaşmasına rağmen idrarda eritrositin olmaması, CK seviyelerinin normalin en az 5 katı olması, LDH, AST, fosfor ve potasyum artışı, kalsiyumun azalması beklenir. En belirgin laboratuvar bulgusu miyoglobin artışıdır. Ancak 6 saat içinde plazmadan temizlendiği için tanı değeri azdır. CK yarı ömrü 48 saattir. Bizim olgularımızda CK değerlerinin 1767 ve 4267 U/L oluşu, AST, ALT, LDH değerlerinin yüksek olması, idrar renginin koyu olup eritrosit olmayışı rabdomiyoliz tanısını destekliyordu. Her iki olguda aşikâr hipotiroidi dışında rabdomiyoliz yapabilecek ek hastalık veya ilaç kullanımı yok- 
tu. CK-MB değerlerinin normal olması miyokard hastalığını dışlamıştır. Tiroid hormon tedavisi ile kliniğin hızlı bir şekilde düzelmesi ve kas enzimlerinin normale gerilemesi hipotiroidi olduğunu desteklemektedir. Klinik bulguların ve laboratuar bulgularının tiroid hormon tedavisine hızlı cevap vermesi nedeniyle kas biyopsisi ve Elektromiyografi (EMG) yapılmadı.

\section{Sonuç}

Acil pratiğinde kas ağrısı, kas güçsüzlüğü şikayetleri ile başvuran ve kas enzimleri yüksek bulunan hipotiroidi hastalarında nadir bir komplikasyon olan rabdomiyoliz ve akut böbrek yetmezliğinin gelişebileceği akılda tutulmalıdır. Bu tür vakalarda tiroid hormon replasmanı yanında konservatif tedavi genellikle yeterlidir.

Hasta Onamı: Olgunun retrospektif tasarımından dolayı onam alınmasına gerek duyulmamıştır.

Hakem Değerlendirmesi: Dış bağımsız.

Yazar Katkıları: Fikir - Abdullah S.; Tasarım - Abdullah S., K.Ç., Ayşegül S.; Denetleme - K.Ç. Ayşegül S.; Kaynaklar - Abdullah S., Ayşegül S.; Malzemeler - Abdullah S., K.Ç., Ayşegül S.; Veri toplanması ve/veya işlemesi - Abdullah S., K.Ç., Ayşegül S.; Analiz ve/veya yorum - Abdullah S., K.Ç., Ayşegül S., S.Ö.; Literatür taraması - Abdullah S., K.Ç., Ayşegül S.; Yazıyı yazan - Abdullah S., Ayşegül S.; Eleştirel İnceleme - K.Ç., S.Ö.

Çıkar Çatışması: Yazarlar herhangi bir çıkar çatışması bildirmemişlerdir.

Finansal Destek: Yazarlar bu çalışma için finansal destek almadıklarını beyan etmişlerdir.

Informed Consent: Due to the retrospective nature of this study, informed consent was waived.

Peer-review: Externally peer-reviewed.
Author Contributions: Concept - Abdullah S.; Design - Abdullah S., K.Ç., Ayşegül S.; Supervision - K.Ç. Ayşegül S.; Funding - Abdullah S., Ayşegül S.; Materials - Abdullah S., K.Ç., Ayşegül S.; Data Collection and/or Processing - Abdullah S., K.Ç., Ayşegül S.; Analysis and/or Interpretation - Abdullah S., K.Ç., Ayşegül S., S.Ö.; Literature Review Abdullah S., K.Ç., Ayşegül S.; Writing - Abdullah S., Ayşegül S.; Critical Review - K.Ç., S.Ö.

Conflict of Interest: No conflict of interest was declared by the authors.

Financial Disclosure: The authors declared that this study has received no financial support.

\section{Kaynaklar}

1. Melli G, Chaudhry V, Cornblath DR. Rhabdomyolysis: an evaluation of 475 hospitalized patients. Medicine (Baltimore) 2005; 84: 377-85.

[CrossRef]

2. Demester N. Diseases of the thyroid. Clinician Reviews 2001; 11: 58-64.

3. Goldman J, Matz R, Mortimer R, Freeman R. High elevations of creatine phosphokinaze in hypothyroidism. JAMA1977; 325-6. [CrossRef]

4. Yarman S, Cikim A, Kurtulmus N. Hipotiroidik Hastalarda Kreatin Fosfokinaz yüksekliği. İst Tıp Fak. Mecmuası 2002; 65: 4.

5. Giampietro O, Clerico A, Buzzigoli G, Del Chicca MG, Boni C, Carpi A. Detection of hypothyroid myopathy by measurement of $\mathrm{V} v a r i o u s$ serum muscle markers - myoglobin, creatine kinase, lactate dehydrogenase and their isoenzymes. Correlations with thyroid hormone levels (free and total) and clinical usefulness. Horm Res 1984; 19: 232-42. [CrossRef]

6. Beyer IW, Karmali R, Demeester-Mirkine N, Cogan E, Fuss MJ. Serum creatine kinase levels in overt and subclinical hypothyroidism. Thyroid1998; 8: 1029-31. [CrossRef]

7. Unal A, Sipahioglu MH, Tokgoz B, Akcakaya M, Coskun R, Oymak O, Utas C. Antihiperlipidemik Tedavi Sonrası Gelişen Rabdomiyoliz: Üç Olgu Sunumu. Erciyes Tıp Dergisi (Erciyes Medical Journal) 2009; 1: 1-4.

8. Rosenson RS. Current overview of statin induced myopathy. Am J Med 2004; 116: 408-16. [CrossRef] 